\title{
AKUNTABILITAS KINERJA INSTANSI PEMERINTAH DALAM PERSPEKTIF TEORI INSTITUSIONAL: SEBUAH PENDEKATAN PENELITIAN CAMPURAN
}

\author{
Zuraifa Nadila $^{1 *}$, Muhammad Ahyaruddin $^{2}$, Agustiawan $^{3}$ \\ 1,2,3 Faculty of Economic and Business, Universitas Muhammadiyah Riau, Indonesia \\ *Corresponding author: nadilazuraifa1@gmail.com
}

\author{
A R T I C L E I N F O \\ Article History: \\ Received: 01 June 2021 \\ Revised: 16 July 2021 \\ Accepted: 23 July 2021 \\ Keywords: \\ Teori Institusional; \\ Isomorfisma Institusional; \\ Akuntabilitas Kinerja; \\ Metode Campuran
}

\begin{abstract}
A B S T R A C T
Penelitian ini bertujuan menguji faktor-faktor yang mempengaruhi akuntabilitas kinerja instansi pemerintah Kota Pekanbaru. Selain itu, penelitian ini juga mengeksplorasi secara lebih mendalam praktik pelaporan akuntabilitas kinerja yang terjadi dalam konteks teori isomorfisma institusional. Metode pengumpulan data dilakukan dengan metode survei kepada 103 orang responden serta wawancara kepada tiga orang pejabat senior yang bekerja pada instansi di lingkungan pemerintah Kota Pekanbaru. Penelitian ini menggunakan pendekatan metode campuran (mix method) dengan desain sekuensial eksplanatori. Teknik analisis data kuantitatif menggunakan regresi linear berganda dan analisis data kualitatif menggunakan metode analisis isi tematik. Hasil penelitian menemukan bahwa faktor-faktor yang mempengaruhi akuntabilitas kinerja instansi pemerintah adalah kejelasan sasaran anggaran, regulasi dan komitmen manajemen. Sedangkan faktor insentif ditemukan tidak berpengaruh signifikan terhadap akuntabilitas kinerja instansi pemerintah. Hasil temuan kualitatif menunjukkan bahwa isomorfisma institusional dalam bentuk koersif, mimetik dan normatif terjadi dalam praktik pelaporan akuntabilitas kinerja instansi pemerintah Kota Pekanbaru. Temuan ini memberi implikasi bahwa teori institusional khususnya isomorfisma institusional memang hadir dalam tata kelola organisasi pemerintahan khususnya pemerintah daerah Kota Pekanbaru.
\end{abstract}

\section{Pendahuluan}

Akuntabilitas kinerja merupakan salah satu perwujudan tata kelola pemerintahan yang baik (good governance) dalam pengelolaan organisasi sektor publik. Sebagai wujud komitmen untuk mengimplementasikan akuntabilitas kinerja instansi pemerintah, diperlukan sebuah sistem yang efektif dan saling terkoordinasi serta aturan yang jelas sebagai acuan bagi instansi pemerintah. Penerapan sistem pengukuran kinerja instansi pemerintah telah diatur dalam Inpres nomor 7 tahun 1999 tentang Akuntabilitas Kinerja
Instansi Pemerintah (AKIP) dan Keputusan Lembaga Administrasi Negara (LAN) nomor 589/IX/6/Y/1999 tentang Pedoman Pelaporan Akuntabilitas Kinerja Instansi Pemerintah. Laporan Akuntabilitas Kinerja Instansi Pemerintah (LAKIP) merupakan alat pelaksanaan akuntabilitas kinerja yang akan dinilai secara transparan, sistematis dan dapat dipertanggungjawabkan (LAN BPKP, 2004).

Fenomena yang masih sering terjadi di pemerintah Kota Pekanbaru yaitu terjadinya keterlambatan atau tidak disiplinnya kepala organisasi perangkat daerah (OPD) dalam 
penyampaian laporan kegiatan sehingga proses untuk merealisasikan inovasi program kegiatan menjadi terhambat yang pada akhirnya berperngaruh terhadap rendahnya akuntabilitas kinerja (Tribunnews, 2019). Instansi Pemerintah, Badan dan Lembaga Negara di Pusat dan Daerah sesuai dengan tugas pokok masing-masing harus memahami lingkup akuntabilitasnya masing-masing, karena akuntabilitas yang diminta meliputi keberhasilan dan juga kegagalan pelaksanaan misi instansi yang bersangkutan (LAN BPKP, 2004). Sihaloho (2005) mengemukakan bahwa sebagian besar instansi pemerintah secara konsisten mengikuti sistem pengukuran kinerja yang dirumuskan oleh Badan Pengawas Keuangan dan Pembangunan (BPKP) dan Lembaga Administrasi Negara (LAN). Namun, dalam sistem pengukuran kinerja yang dianut tersebut, efisiensi bukanlah suatu ukuran kinerja yang harus dikembangkan. Hal tersebut selanjutnya menjadikan instansi lebih cenderung untuk mengabaikan aspek efisiensi.

Hal itu mengindikasikan bahwa niat penggunaan sistem pengukuran kinerja lebih didominasi oleh tekanan luar (coercive isomorphism), yakni kepatuhan kepada aturan baku formal, tanpa melakukan pengembangan sistem pengukuran kinerja secara normatif. Fenomena ini sejalan dengan pendapat Gudono (2014) yang mengemukakan bahwa paksaan atau tekanan dari suatu peraturan atas suatu pelaksanaan mekanisme kerja dapat menimbulkan masalah berupa ketaatan semu oleh instansi yang dituntut.

Di Indonesia, sistem pengukuran kinerja untuk pemerintah, baik pusat maupun daerah, mulai diatur semenjak dikeluarkannya Instruksi Presiden (Inpres) Nomor 7 Tahun 1999. Inpres tersebut mengamanatkan dilaksanakannnya Sistem Akuntabilitas Kinerja Instansi Pemerintah (SAKIP) di semua level instansi pemerintahan. Akan tetapi, hingga 2013, implementasi SAKIP masih menemui berbagai permasalahan (Sofyani, dan Akbar, 2013). Dari segi teoritisnya, lahirnya Inpres No. 7 Tahun 1999 adalah bentuk adanya isomorpisma mimetik atau upaya meniru yang dilakukan pemerintah Indonesia terhadap pemerintahan di negara lain yang dinilai lebih maju penyelenggaraan pemerintahannya. Isomorfisme yang sifatnya mimetik atau imitasi dapat memicu masalah, yakni kecenderungan untuk terjebak pada pelaksanaan suatu mekanisme kerja yang sifatnya sebatas seremonial formal, bukan berorientasi pada substansi (Gudono, (2014). Isomorfisma mimetik atau meniru-niru terjadi ketika teknologi organisasi kurang dipahami (March et al., 1976), ketika tujuan yang ambigu, atau ketika terdapat ketidakpastian lingkungan yang simbolik (Wijaya dan Akbar, 2013), maka organisasi akan cenderung menjadikan diri mereka sebagai model yang sama seperti organisasi lain dan mendorong organisasi untuk melakukan imitasi (Sofyani dan Akbar, 2013)

Menurut DiMaggio dan Powell (1983) menjelaskan bahwa isomorfisme normatif yang terkait dengan profesionalisme. Perubahan institusional dapat berdampak pada masalah karakter dan integritas organisasi. Strategi integritas merupakan sesuatu yang lebih luas, lebih mendalam, dan juga lebih menuntut daripada inisiatif kepatuhan atas hukum. Kepatuhan atas hukum dan peraturan akan terwujud dengan baik ketika diikuti oleh komitmen manajemen yang kuat.

Penelitian ini dilakukan dengan tujuan untuk menguji faktor-faktor yang mempengaruhi akuntabilitas kinerja instansi pemerintah Kota Pekanbaru. Selain itu, penelitian ini juga mengeksplorasi secara lebih mendalam praktik pelaporan akuntabilitas kinerja yang terjadi dalam konteks teori isomorfisma institusional. Ada dua pertanyaan khusus yang perlu dieksplorasi secara lebih dalam yaitu: (1) Apakah isomorfisma institusional terjadi dalam praktik pelaporan akuntabilitas kinerja instansi pemerintah kota pekanbaru?; dan (2) Apakah pemerintah daerah menggunakan informasi LAKIP dalam pengambilan keputusan?

Penelitian ini diharapkan bisa memberikan kontribusi secara teoritis dalam pengembangan literature khususnya pada konsep teori isomorfisma institusional. Penelitian ini juga diharapkan memberikan implikasi praktis kepada pemerintah khususnya organisasi pemerintah daerah untuk mengidentifikasi factor pendorong peningkatan akuntabilitas kinerja organisasi. Sehingga kebijakan yang dilakukan bisa mengarah pada pancapaian kinerja organisasi yang rill, bukan hanya 
sekedar kinerja semu untuk mendapatkan legitimasi eksternal.

\section{Tinjauan Pustaka dan Pengembangan Hipotesis}

\subsection{Teori Institusional (Institutional Theory)}

Teori institusional (institutional theory) atau teori kelembagaan dasar pikirannya adalah terbentuknya organisasi oleh karena tekanan lingkungan institusional yang akan menyebabkan terjadinya institusionalisasi. DiMaggio dan Powell (1983) mengidentifikasi tiga mekanisme untuk perubahan dan upaya dilakukan organisasi untuk menyesuikan diri dengan lingkungan (institusional isomorphic). Pertama, isomorfisma koersif, merupakan hasil dari tekanan formal maupun informal yang diberikan organisasi dengan organisasi lainnya mereka saling bergantung dan didalamnya terdapat fungsi organisasi. Kedua, isomorphisma mimetic atau meniru-niru, terjadi ketika tujuan yang ambigu, atau ketidakpastian lingkungan yang simbolik maka organisasi akan cenderung menjadikan diri mereka sebagai model yang sama sepeti organisasi laindan mendorong organisasi untuk melakukan imitasi. Ketiga, isomorphism normatif yang berkaitan dengan profesionalisme (Ahyaruddin dan Akbar, 2016).

\subsection{Kejelasan Sasaran Anggaran dan Akuntabilitas Kinerja}

Berdasarkan Inpres nomor 7 tahun 1999 menyatakan bahwa akuntabilitas kinerja instansi pemerintah merupakan perwujudan kewajiban suatu instansi pemerintah untuk mempertanggungjawabkan keberhasilan atau kegagalan pelaksanaan misi organisasi dalam mencapai tujuan dan sasaran yang telah ditetapkan memalui pertanggungjwaban secara periodik. Kejelasan sasaran anggaran menunjukkan luasnya tujuan anggaran yang dinyatakan secara spesifik, jelas, dan dapat dimengerti oleh siapa saja yang bertanggungjawab. Kennis (1979) menemukan bahwa manajer memberi reaksi positif dan secara relatif sangat kuat untuk meningkatkan kejelasan sasaran anggaran. Singkatnya waktu pembahasan anggaran instansi Pemerintah menyulitkan pembuat kebijakan untuk menjalankan fungsi anggaran secara maksimal, sehingga rentan terjadi kesalahan, ketidaktepatan sasaran, dan hanya mengacu pada program tahun sebelumnya yang tidak konstektual dengan kebutuhan mendatang. kondisi ini memicu timbulnya fenomena yang disebut isomorpisme mimetic.

Hasil Penelitian Mulyadi dan Efendy (2018) mengatakan pada hasil penelitiannya bahwa kejelasan sasaran anggaran secara simultan dan parsial berpengaruh signifikan terhadap Akuntabilitas Kinerja Instansi Pemerintah. Hal ini sejalan dengan Cahyani dan Utama (2015) dan Zulfiandri (2017). Berdasarkan teori dan penelitian sebelumnya maka hipotesis dirumuskan sebagai adalah:

H1:Diduga Kejelasan sasaran anggaran berpengaruh terhadap Akuntabilitas Kinerja Instansi Pemerintah Daerah Kota Pekanbaru.

\subsection{Insentif dan Akuntabilitas Kinerja}

Insentif merupakan pemberian uang di luar gaji yang dilakukan oleh pemimpin organisasi sebagai pengakuan terhadap kinerja pegawai kepada organisasi. Apabila insentif yang diberikan organisasi sudah tepat, maka insentif yang diberikan akan meningkatkan kinerja pegawai. Kinerja merupakan hasil dan prilaku kerja yang dihasilkan oleh seorang pegawai sesuai dengan perannya dalam organisasi pada suatu periode tertentu. Kinerja yang baik adalah salah satu faktor yang sangat penting dalam upaya untuk meningkatan kinerja dan produktivitas.

Akan tetapi dalam hal ini insentif mengadopsi tuntutan profesional terhadap organisasi yang memiliki perasaan bertanggungjawab yang kuat terhadap organisasi diduga akan menerapkan dan mengukuran kinerja secara baik dan melakukan pengembangan sistem pengukuran kinerja secara baik pula. Kondisi ini kemudian memicu lahirnya fenomena yang disebut isomorpisme normatif.

Hasil penelitian Almizan (2019) menyatakan bahwa insentif berpengaruh terhadap kinerja instansi pemerintah dan hal ini sejalan dengan penelitian (Primarisanti dan Akbar, 2015). Sehinga Jika insentif yang diterima tidak dikaitkan dengan prestasi kerja tetapi bersifat pribadi, maka mereka akan merasakan adanya ketidakadilan, dan 
ketidakadilan ini dapat mengakibatkan ketidakpuasan yang pada gilirannya dapat mempengaruhi perilaku kerja dikarenakan hanya sebagai tuntutan profesional dalam bekerja.

H2:Diduga Insentif berpengaruh terhadap Akuntabilitas Kinerja Instansi Pemerintah Daerah Kota Pekanbaru.

\subsection{Regulasi dan Akuntabilitas Kinerja}

Setiap organisasi Perangkat Daerah wajib mematuhi peraturan maupun undang-undang yang dibuat oleh pemerintah. Dalam hal ini peraturan atau regulasi bersifat memaksa bagi suatu organisasi untuk melaksanakannya. Kondisi ini menimbulkan tekanan atau memaksa untuk melakukannya maka timbul lah fenomena isomorphsm coerciv yang mana organisasi terpaksa melakukan adopsi suatu struktur atau aturan. Isomorfisme koersif selalu terkait dengan segala hal yang terhubung dengan lingkungan di sekitar organisasi. Isomorfisme koersif (coercive isomorphism) merupakan hasil dari tekanan formal dan informal yang diberikan pada organisasi oleh organisasi lain dimana organisasi tergantung dengan harapan budaya masyarakat di mana organisasi menjalankan fungsinya (DiMaggio dan Powell, 1983). Diperkuat lagi dengan hasil Penelitian Ahyaruddin dan Akbar (2017) dan Budiarto dan Damayanti (2020) menyatakan bahwa Regulasi memberikan pengaruh signifikan terhadap akuntabilitas. Berdasarkan uraian tersebut, maka hipotesis yang di rumuskan adalah sebagai berikut:

\section{H3:Regulasi berpengaruh terhadap} akuntabilitas kinerja instansi pemerintah

\subsection{Komitmen Manajemen dan Akuntabilitas Kinerja}

Komitmen manajemen merupakan salah satu faktor yang sangat penting dalam mendorong perwujudan akuntabilitas kinerja organisasi sektor publik. Komitmen manajemen merupakan hal yang paling penting dalam proses mendesain, mengimplementasikan, dan menggunakan sistem pengukuran kinerja. Sejalan dengan pandangan isomorpisma institusional, komitmen manajemen secara normatif adalah bentuk dari perjuangan kolektif anggota organisasi untuk menentukan kondisi dan metode kerja mereka untuk tujuan yang mengarah kepada profesionalisme (DiMaggio dan Powell, 1983).

Manajemen yang memiliki perasaan bertanggungjawab yang kuat terhadap organisasi diduga akan menerapkan sistem pengukuran kinerja secara baik dan melakukan pengembangan sistem pengukuran kinerja secara baik pula. Kondisi ini kemudian memicu lahirnya fenomena yang disebut isomorfisma normatif. Hasil penelitian Putri dan Kamilah (2019) dan Budiarto dan Damayanti (2020) mengatakan bahwa komitmen manajemen berpengaruh terhadap akuntabilitas kinerja instansi pemerintah. Hal ini sejalan dengan peneltian Rangkuti (2018). Berdasarkan uraian tersebut, maka hipotesis yang di rumuskan adalah sebagai berikut:

H4:Komitmen manajemen berpengaruh terhadap akuntabilitas kinerja instansi pemerintah

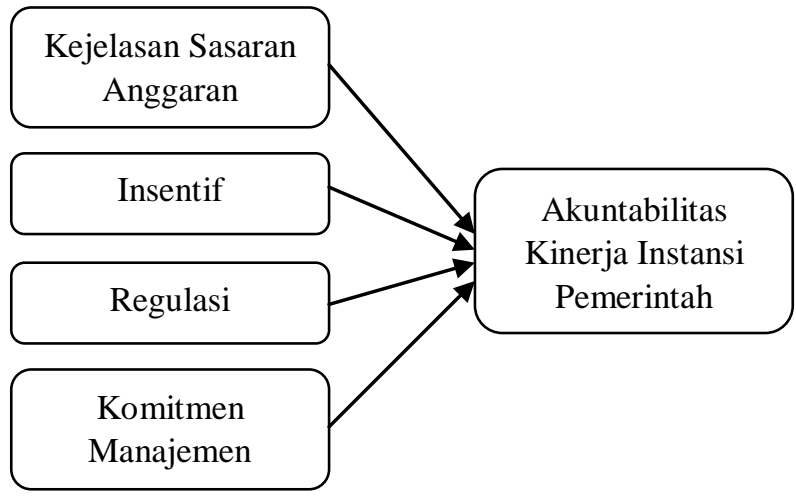

Gambar 1. Model Penelitian

\section{Metode Penelitian}

\subsection{Desain Penelitian dan Analisis Data}

Penelitian ini menggunakan pendekatan metode campuran (mixed method), yaitu menerapkan kombinasi pendekatan kuantitatif dan kualitatif. Desain yang digunakan adalah desain sekuensial eksplanatoris (explanatory sequential design), yaitu dimulai dengan membangun tahap kuantitatif terlebih dahulu, kemudian menindaklanjuti pada hasil yang lebih spesifik dengan tahap kualitatif untuk menjelaskan hasil kuantitatif tersebut secara lebih mendalam (Creswell dan Clark, 2011).

Penelitian ini dilakukan pada organisasi perangkat daerah (OPD) Kota Pekanbaru dengan jumlah sampel 103 responden dari pejabat eselon II, III dan IV. Analisis data dilakukan menggunakan dua metode. Untuk 
data kuantitatif dengan menggunakan regresi linier berganda dalam pengujian hipotesis. Sedangkan data kualitatif berupa wawancara dianalisis menggunakan analisis isi tematik (Ahyaruddin dan Akbar, 2016). Wawancara dilakukan kepada tiga orang informan kunci menggunakan metode semi terstruktur dan terbuka. Pemilihan informan tersebut didasarkan pada hasil analisis scatter plot dari data kuantitatif yang diperoleh sebelumnya. tiga responden tersebut terdiri dari pejabat senior yang memiliki jabatan eselon IV dengan posisi: kepala sub bidang keuangan, kepala seksi pembangunan dan pemberdayaan masyarakat dan kepala sub bagian program.

\subsection{Pengukuran Variabel}

Variabel akuntabilitas kinerja instansi pemerintah diukur dengan instrument 10 butir pernyataan yang digunakan Agustin (2018) dengan beberapa indikator, yaitu: pemahaman kejelasan sasaran anggaran suatu program, penetapan visi dan misi sesuai dengan rencana stratejik organisasi, penetapan indikator kinerja untuk setiap kegiatan, analisis keuangan, pembuatan laporan keuangan, pengecekan jalannya program, pengendalian pelaksanaan kegiatan, akomodir setiap perubahan pada kegiatan, kegunaan LAKIP dan kaitan antara pencapaian kinerja dengan program dan kebijakan.

Variabel kejelasan sasaran anggaran diukur dengan instrumen 8 butir pernyataan yang digunakan oleh Agustin (2018) dengan indikator, yaitu: kejelasan rencana kerja dan anggaran, kesesuaian rencana kerja dan, sasaran anggaran yang jelas dan spesifik, keahlian dan pengetahuan, faktor yang mendukung tujuan-tujuan instansi, ketepatan anggaran dengan realisasi, faktor-faktor yang mempengaruhi pelaksanaan anggaran secara efektif dan tahun anggaran sebagai harapan dan evaluasi kinerja bagi instansi.

Variabel insentif diukur menggunakan item-item pertanyaan dari instrumen dari Ahyaruddin dan Akbar (2017) dengan indikator terkait dengan tujuan insentif. Variabel regulasi diukur menggunakan itemitem pertanyaan dari instrumen Ahyaruddin dan Akbar (2017) dengan indikator yang terkait dengan keterlibatan staf maupun pimpinan dalam aktifitas yang berhubungan dengan laporan akuntabilitas kinerja instansi pemerintah (LAKIP).

Variabel komitmen manajemen diukur dengan instrumen 8 butir pernyataan yang digunakan Ahyaruddin dan Akbar (2017) dengan indikator yang mempengaruhi komitmen manajeman: keterlibatan staf maupun pimpinan dalam aktifitas yang berhubungan dengan laporan akuntabilitas kinerja instansi pemerintah.

\section{Hasil Penelitian dan Pembahasan}

\subsection{Gambaran Umum Responden}

Rincian profil responden berdasarkan hasil penyebaran angket kuesioner dapat dilihat pada tabel 1 .

Tabel 1. Profil Demografi Responden

\begin{tabular}{lcc}
\hline Profil Responden & Jumlah & Persentase \\
\hline Gender & & \\
- Laki-laki & 52 & $50.49 \%$ \\
- Perempuan & 51 & $49.51 \%$ \\
\hline Jabatan & & \\
- Eselon II & 1 & $0.97 \%$ \\
- Eselon III & 17 & $16.50 \%$ \\
- Eselon IV & 85 & $85.52 \%$ \\
\hline Umur & & \\
- <30 Tahun & 6 & $5.83 \%$ \\
- 31-40 Tahun & 22 & $21.36 \%$ \\
- 41-50 Tahun & 57 & $55.34 \%$ \\
- >50 Tahun & 18 & $17.48 \%$ \\
\hline Pendidikan & 0 & $0 \%$ \\
- Diploma & 0 & $0 \%$ \\
- Sarjana & 56 & 54.37 \\
- Master & 47 & $45.63 \%$ \\
- Doktor & 0 & $0 \%$ \\
\hline Pengalaman Kerja & & \\
- 2-5 Tahun & 8 & $7.77 \%$ \\
- 6-10 Tahun & 24 & $23.30 \%$ \\
- 11-15 Tahun & 26 & $25.24 \%$ \\
- >15 Tahun & 45 & $43.69 \%$ \\
\hline
\end{tabular}

Sumber: Data olahan (2021)

\subsection{Hasil Analisis Kuantitatif}

Pada tabel 2 terlihat statistik deskriptif yang mencerminkan sebaran data pada masing-masing variabel penelitian yaitu kejelasan sasaran anggaran, insentif, regulasi, komitmen manajemen, dan akuntabilitas kinerja instansi pemerintah. Dari tabel tersebut dapat terlihat nilai mean lebih besar dari 
standar deviasi sehingga dapat disimpulkan bahwa terdapat penyebaran data yang baik.

Tabel 2. Statistik Deskriptif

\begin{tabular}{|c|c|c|c|c|c|}
\hline Variabel & $\mathrm{N}$ & Min & $\operatorname{Max}$ & Mean & Std. Dev. \\
\hline $\begin{array}{l}\text { - Akuntabilitas } \\
\text { Kinerja }\end{array}$ & 103 & 32 & 50 & 42.83 & 4.899 \\
\hline $\begin{array}{l}\text { - Kejelasan } \\
\text { Sasaran } \\
\text { Anggaran }\end{array}$ & 103 & 25 & 40 & 32.15 & 3.069 \\
\hline - Insentif & 103 & 4 & 10 & 7.46 & 1.607 \\
\hline - Regulasi & 103 & 2 & 10 & 7.71 & 1.588 \\
\hline $\begin{array}{l}\text { - Komitmen } \\
\text { Manajemen }\end{array}$ & 103 & 18 & 40 & 32.50 & 4.293 \\
\hline Valid N (listwise) & 103 & & & & \\
\hline
\end{tabular}

Selanjutnya, peneliti melakukan uji kualitas data dan uji asumsi klasik sebelum dilakukan pengujian hipotesis menggunakan regresi linier berganda. Hasil uji kualitas data menggunakan uji validitas dan reliabilitas telah memenuhi ketentuan yang disyaratkan dengan melihat nilai pearson correlation dan cronbach's alpha. Uji asumsi klasik dilakukan dengan menggunakan uji normalitas, heteroskedastisitas, dan multikolinieritas dan semuanya menunjukkan hasil yang baik sesuai dengan ketentuan yang disyaratkan. Kemudian peneliti melanjutkan tahap pengujian hipotesis menggunakan analisis regresi linier berganda yang terlihat pada tabel 3 .

Tabel 3. Hasil Regresi Linier Berganda

\begin{tabular}{lcccc}
\hline & \multicolumn{3}{c}{ Unstandardized } \\
& Coefficients & \\
\cline { 2 - 4 } Model & $\mathrm{B}$ & Etd. & & \\
\hline (Constant) & 3.916 & 3.889 & 1.007 & .316 \\
Kejelas. Sasaran Angg. & .420 & .101 & 4.157 & .000 \\
Insentif & .317 & .185 & 1.718 & .089 \\
Regulasi & 1.667 & .205 & 8.131 & .000 \\
Komitmen Manajemen & .314 & .073 & 4.317 & .000 \\
\hline Sumber: Data Olahan (2021) & & &
\end{tabular}

Kejelasan sasaran anggaran berpengaruh terhadap akuntabilitas kinerja instansi pemerintah Kota Pekanbaru dengan signifikan $0.000<0,05$. Hal ini menyimpulkan bahwa sasaran anggaran yang jelas memiliki pengaruh yang besar terhadap akuntabilitas kinerja instansi pemerintah. Semakin jelas tujuan dan kejelasan sasaran anggaran yang ditargetkan dan diterapkan, maka akan semakin baik akuntabilitas kinerja yang dihasilkan pemerintah. Temuan ini konsisten dengan literature sebelumnya (Mulyadi dan Efendy, 2018; Cahyani dan Utama, 2015; Zulfiandri, 2017) yang mengatakan bahwa kejelasan sasaran anggaran berdampak terhadap akuntabilitas kinerja. Singkatnya waktu pembahasan anggaran instansi Pemerintah menyulitkan pembuat kebijakan untuk menjalankan fungsi anggaran secara maksimal, sehingga menjadi rentan dan terjadi kesalahan, ketidaktepatan sasaran, dan hanya mengacu pada program tahun sebelumnya yang tidak konstektual dengan kebutuhan mendatang. Kondisi ini lah yang kemudian memicu lahirnya fenomena yang disebut isomorfisma normatif.

Insentif tidak berpengaruh terhadap akuntabilitas kinerja instansi pemerintah Kota Pekanbaru dengan signifikan 0,089>0,05. Hasil ini dikarenakan dimana sesuai fakta dilapangan tidak semua instansi pemerintah daerah Kota Pekanbaru memberlakukan sistem reward atau insentif dalam pelaksanaan sistem pengukuran kinerjanya (SAKIP). Kebijakan insentif bertujuan agar implementasi sistem pengukuran kinerja tidak hanya karena tuntutan, atau koersif, tetapi dapat meningkatkan profesionalitas dan menyentuh level isomorfisma normatif. Hasil ini berbeda dengan hasil penelitian (Almizan, 2019) yang mengatakan bahwa insentif berpengaruh terhadap akuntabilitas kinerja.

Regulasi berpengaruh terhadap akuntabilitas kinerja instansi pemerintah Kota Pekanbaru dengan signifikan $0.000<0,05$. Hal ini menyimpulkan bahwa regulasi merupakan salah satu faktor yang mendukung keberhasilan pelaksanaan pengukuran akuntabilitas kinerja. Pejabat pemerintah dalam melaksakan tugasnya baik dalam hal penilaian kinerja, pelaporan kinerja, peningkatan kinerja, evaluasi dan implementasi akuntabilitas kinerja didorong oleh regulasi dan peraturan. Isomorfisma koersif (coercive isomorphism) merupakan hasil dari tekanan formal dan informal yang diberikan pada organisasi oleh organisasi lain dimana organisasi tergantung dengan harapan budaya masyarakat di mana organisasi menjalankan fungsinya. Penelitian ini sejalan dengan (Ahyaruddin dan Akbar, 2017) mengatakan bahwa regulasi berpengaruh terhadap akuntabilitas. 
Komitmen manajemen berpengaruh terhadap akuntabilitas kinerja instansi pemerintah Kota Pekanbaru dengan signifikan $0.000<0,05$. Dalam hal ini Akuntabilitas kinerja akan berjalan dengan baik jika didukung oleh komitmen manajemen organisasi yang tinggi karena organisasi dengan komitmen manajemen yang kuat akan lebih berpeluang mencapai hasil yang diinginkan untuk menghasilkan kinerja yang lebih baik daripada organisasi yang tidak memiliki komitmen manajemen. Komitmen manajemen ini sangat penting untuk mencapai akuntabilitas kinerja karena semakin baik komitmen manajemen suatu organisasi maka akan semakin baik pula kinerja yang dihasilkan. Sejalan dengan pandangan isomorphism institusional, komitmen manajemen secara normatif adalah bentuk dari perjuangan kolektif anggota organisasi untuk menentukan kondisi dan metode kerja mereka untuk tujuan yang mengarah kepada profesionalisme (DiMaggio dan Powell, 1983). Penelitian ini sejalan dengan Putri dan Kamilah (2019) dan Budiarto dan Damayanti (2020).

\subsection{Analisis Data Kualitatif}

Creswell dan Clark (2011) mengatakan bahwa salah satu cara untuk memilih sampel yang akan menjadi responden wawancara adalah dengan memilih sebaran data outlier dari hasil pengujian data kuantitatif. Berdasarkan data kuantitatif yang telah terkumpul, peneliti membuat grafik scatter plot dari nomor responden menggunakan software microsoft excel 2013 untuk melihat sebaran data yang outlier yang akan menjadi reponden daalm wawancara ini (Ahyaruddin dan Akbar 2016). Gambar 2 menunjukkan tiga informan yang dipilih berdasarkan data outlier pada analisis kuantitatif.

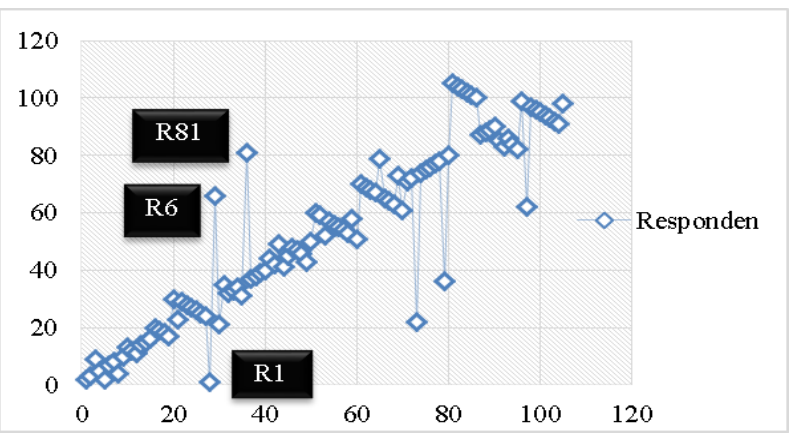

Gambar 2. Scatter Plot Sebaran Data Responden

\subsection{Pembahasan}

Hasil analisis isi tematik berdasarkan hasil wawancara kepada responden mengenai isomorfisma institusional dan keterkaitan akuntabilitas kinerja dijelaskan secara lebih mendalam berikut ini:

\section{Isomorfisma Koersif}

Teori institusional dasar pikirnya adalah terbentuknya organisasi karena tekanan lingkungan institusional yang menyebabkan terjadinya institusionalisasi. Hal ini hadir di Indonesia khususnya daerah Kota Pekanbaru, yang mana pelaksanaan pengukuran kinerja, penyusunan dan laporan akuntabilitas kinerja instansi pemerintah dilakukan karena adanya rasa ketergantungan kepada pemerintah pusat sesuai dengan Inpres Nomor 7 Tahun 1999. Setiap organisasi perangkat daerah wajib mematuhi peraturan maupun undang-undang yang dibuat oleh pemerintah. Dalam hal ini peraturan atau regulasi bersifat memaksa bagi suatu organisasi untuk melaksanakannya. Kondisi ini menimbulkan tekanan atau memaksa untuk melakukannya yang mana organisasi terpaksa melakukan suatu struktur atau aturan. Hal ini sesuai dengan fakta dilapangan dan dikonfirmasi langsung oleh pejabat pemerintah bahwa apa yang mereka lakukan harus sesuai dengan aturan dan regulasi yang berlaku.
"tidak ada regulasi pasti tidak bisa dilaksanakan. Iya karena untuk dasar penyusunan laporan akuntabilitas tentu merujuk pada undang-undang nah sekarang terakhir Permenpan-RB nomor 12 tahun 2015 tentang pedoman evaluasi dan implementasi sistem akuntabilitas kinerja instansi pemerintah. Seluruh opd pasti berpedoman pada Permenpan- $R B$ itu untuk penyusunan kemudian nanti ada di buat dalam bentuk Perwako (peraturan walikota) untuk pedoman penyusunan LAKIP $O P D$ ”. (R1, Kasubag program BPKAD)

\section{Isomorfisma Mimetik}

Isomorfisma mimetik adalah kecenderungan organisasi untuk memodelkan dirinya pada perilaku organisasi lain (DiMaggio dan Powell, 1983) muncul sebagai tanggapan untuk suatu ketidakpastian akan suatu standar tertentu. Isomorfisma mimetik termasuk di dalamnya benchmarking dan mengidentifikasi pelaksanaan terbaik yang ada di lapangan. Ketidakpastian lingkungan sering terjadi didalam setiap organisasi perangkat 
daerah (lembaga pemerintah). Ketidakpastian lingkungan bisa jadi disebabkan berbagai hal dari luar organisasi. Seperti perubahan kebijakan-kebijakan dan peraturan yang tidak menentu dalam setiap waktu dan perbedaan peraturan yang ada akibat suatu dugaan lainnya. Ketidakpastian lingkungan merupakan rasa ketidakmampuan seseorang atau organisasi memperkirakan sesuatu secara akurat dari seluruh faktor sosial dan fisik yang secara langsung mempengaruhi perilaku pembuatan keputusan orang-orang dalam organisasi tersebut.

Hal ini dikonfirmasi sendiri oleh pejabat pemerintah bahwa ketidakpastian lingkungan sering terjadi dalam setiap organisasi salah satunya dan dikonfirmasi oleh pejabat pemerintah kota pekanbaru adalah format atau template laporan akuntabilitas kinerja instansi pemerintah. Ketidakpastian lingkungan bisa disebabkan oleh berbagai hal dari luar organisasi. Sehingga, yang terjadi adalah mereka akan mengikuti atau meniru organisasi lain.

"ada bakunya, yang udah dibuat dari badan keuangan daerah yang sifatnya baku. Tapi yang sifatnya baku itu disesuaikan dengan kegiatan di opd masing-masing tak kan mungkin, ya saya contohkan lah kalau saya kepala seksi pembangunan dan pemberdayaan masyarakat itu tidak mungkin saya sama dengan kasi hahaha. Umpamanya di dinas koperasi memiliki tugas dan pokok fungsi yang berbeda. Jadi disesuaikan aja”. (R81, Kasi Pembangunan dan Pemberdayaan Masyarakat Kecamatan Sukajadi).

\section{Isomorfisma Normatif}

DiMaggio dan Powell (1983) menyatakan bahwa ismorfisma normatif terkait dengan profesionalisme. Tekanan normatif dalam organisasi sektor publik berasal dari kelompok profesional seperti konsultan atau perguruan tinggi melalui berbagai seminar, pelatihan, dan pendampingan. Kelompok profesional ini menjadi sangat penting untuk mengurangi kesalahan dan untuk meningkatkan suksesnya pelaksanaan pelaporan akuntabilitas kinerja (Ahyaruddin dan Akbar, 2016). Organisasi perangkat daerah (OPD) Kota Pekanbaru menggunakan tenaga ahli professional yang berperan membantu instansi pemerintah:

"Tapi itu sebeneranya bukan untuk di penyusunan LAKIP saja, tapi untuk seluruh OPD bagi bidang yang membutuhkan. Kami itu ada untuk pemanfaatan tenaga ahli. Tenaga ahli yang di SK kan oleh Walikota”. (R1, Kasubag Program BPKAD Kota Pekanbaru)

Penelitian ini menemukan bahwasannya pemerintah daerah Kota Pekanbaru menggunakan LAKIP dalam pengambilan keputusan sebagai mana fakta dilapangan dari beberapa pejabat menyatakan bahwa informasi LAKIP sebagai bahan pertimbangan programprogram dan satu elemen yang penting untuk meningkatkan kinerja dan prestasi-prestasi suatu organisasi.

"LAKIP ini ya, tujuannya untuk menghasilkan informasi yang relevanlah atas kinerja program atau organisasi kita, kalau dibilang informasi dalam lakip digunakan untuk apa? ya,untuk mengambilkan keputusan. informasi ini yang akan kita gunakan ya kan, untuk mengambil keputusan,terus bahan pertimbanganpertimbangan untuk program-program,targettarget selanjutnya juga”. (R81, Kasi Pembangunan dan Pemberdayaan Masyarakat Kecamatan Sukajadi)

"gini, gini dek LAKIP ini ya ya bisa dibilang dan dianggap bisa mempengaruhi penggunaan informasi kinerja, karena apa?,dia itu bisa dikatakan elemen yang penting untuk peningkatan kinerja organisasi”. (R6, Kasubag Keuangan Dinas Koperasi Usaha Kecil \& Menengah)

\section{Kesimpulan}

Hasil penelitian yang dilakukan mengungkapkan beberapa temuan. Pertama, kejelasan sasaran anggaran berpengaruh terhadap akuntabilitas kinerja instansi pemerintah Kota Pekanbaru. Hal ini menyimpulkan bahwa sasaran anggaran yang jelas memiliki pengaruh yang besar terhadap akuntabilitas kinerja instansi pemerintah. Semakin jelas tujuan dan kejelasan sasaran anggaran yang ditargetkan dan diterapkan, maka akan semakin baik akuntabilitas kinerja yang dihasilkan pemerintah. Kedua, insentif tidak berpengaruh terhadap akuntabilitas kinerja instansi pemerintah Kota Pekanbaru. Hasil ini dikarenakan dimana sesuai fakta dilapangan tidak semua instansi pemerintah daerah Kota Pekanbaru memberlakukan sistem reward atau insentif dalam pelaksanaan sistem pengukuran kinerjanya (SAKIP). Ketiga, Regulasi berpengaruh terhadap akuntabilitas kinerja instansi pemerintah Kota Pekanbaru. Hal ini menyimpulkan bahwa regulasi merupakan 
salah satu faktor yang mendukung keberhasilan pelaksanaan pengukuran akuntabilitas kinerja. Keempat, komitmen manajemen berpengaruh terhadap akuntabilitas kinerja instansi pemerintah Kota Pekanbaru. Dalam hal ini Akuntabilitas kinerja akan berjalan dengan baik jika didukung oleh komitmen manajemen organisasi yang tinggi karena organisasi dengan komitmen manajemen yang kuat akan lebih berpeluang mencapai hasil yang diinginkan untuk menghasilkan kinerja yang lebih baik daripada organisasi yang tidak memiliki komitmen manajemen.

Selain itu, penelitian ini memberikan kesimpulan bahwa isomorfisma institusional memang terjadi dalam pelaksanaan pelaporan akuntabilitas kinerja instansi pemerintah Kota Pekanbaru. Berdasarkan jawaban dari responden dan pembahasan yang disajikan di atas terungkap bahwa isomorfisma koersif, mimetic dan normatif ini memang hadir dalam tata kelola organisasi pemerintahan Indonesia khususnya pemerintah daerah kota pekanbaru. Informasi LAKIP yang disampaikan oleh organisasi pemerintah Kota Pekabaru digunakan dalam proses pengambilan keputusan. Sebagai mana fakta dilapangan bahwa informasi LAKIP sebagai bahan pertimbangan penyusunan program serta salah satu elemen yang penting untuk meningkatkan kinerja dan prestasi suatu organisasi.

Penelitian ini memiliki beberapa keterbatasan antara lain: Pertama, jumlah responden yang mengisi angket hanya 103 orang dan responden yang diwawancara hanya berjumlah tiga orang tentunya masih kurang untuk menggambarkan dan mendeskripsikan keadaan yang sesungguhnya. Kedua, Penelitian ini dilaksanakan selama Pandemi Covid-19. Keterbatasan waktu dan tenaga dikarenakan pejabat pemerintah yang sedang work from home (WFH) yang dapat mempersempit ruang gerak peneliti dan sedikit lebih lama dalam penyebaran angket penelitian dan menentukan waktu untuk wawancara.

Penelitian ini memberikan implikasi secara teoritis dalam memperkuat penjelasan teori institusional dalam konteks organisasi sektor publik. Berdasarkan fakta di lapangan yang telah dikonfirmasi bahwa isomorfisma institusional (koersif, mimetic dan normatif) memang hadir dalam tata kelola organisasi pemerintahan Indonesia khususnya pemerintah daerah Kota Pekanbaru. Hasil penelitian ini juga memberikan kontribusi kepada pemerintah daerah untuk menerapkan penganggaran berbasis kinerja untuk mempermudah dalam menentukan program yang bersifat prioritas dan pendukung, mengubah paradigma kerja menjadi kinerja dengan menyederhanakan sasaran dan indikatornya. Terakhir, pemerintah perlu meningkatkan pemahaman dan komitmen setiap pimpinan instansi dalam menerapkan SAKIP dan menyusun LAKIP. Hal ini karena komitmen manajemen memberikan kontribusi besar terhadap peningkatan kinerja dan akuntabilitas.

\section{Daftar Pustaka}

Agustin, K. (2018). Pengaruh Kejelasan Sasaran Anggaran, Pengendalian Akuntansi, Sistem Pelaporan dan Ketaatan Peraturan Perundangan Terhadap Akuntabilitas Kinerja Instansi Pemeritah (Studi pada SKPD Di Pemerintah Kota Yogyakarta). Skripsi Fakultas Ekonomi Universitas Islam Indonesia. Yogyakarta.

Ahyaruddin, M., \& Akbar, R. (2016). The relationship between the use of a performance measurement system, organizational factors, accountability, and the performance of public sector organizations. Journal of Indonesia Economy and Business. Vol. 31, No.1. pp. $1-22$.

Ahyaruddin, M., \& Akbar, R. (2017). Akuntabilitas dan kinerja instansi pemerintah: semu atau nyata? Jurnal Akuntansi \& Auditing Indonesia, 12(2), 105-117.

https://doi.org/10.20885/jaai.vol21.iss2.art 3.

Almizan. (2019). Faktor-Faktor yang Mempengaruhi Akuntabilitas Kinerja Instansi Pemerintah: Peran Komitmen Manajemen dan Insentif sebagai Variabel Pemoderasi.

Budiarto, D. S., \& Damayanti, D. (2020). Pengujian Struktural Pada Komitmen Manajemen, Transparansi dan 
Akuntabilitas Pemerintah Daerah. Jurnal Akuntansi dan Bisnis, Vol 20, No.1.

Cahyani, N.M.M, \& Utama, I.M.K. (2015). Pengaruh Kejelasan Sasaran Anggaran,Pengendalian Akuntansi Dan Sistem Pelaporan Pada Akuntabilitas Kinerja. E-Jurnal Akuntansi, 10(3), 825840.

Creswell, J. W. \& Clark, V. L. P. (2011). Designing and Conducting Mixed Methods Research (Second Edi). Sage Publication.

DiMaggio, P. J. \& Powell, W. W. (1983). The Iron Cage Revisited: Institutional Isomorphism and Collective Rationality in Organizational Fields. American Sociological Review.

Gudono. (2014). Teori organisasi (3rd ed.). BPFE. Yogyakarta.

Kennis. (2011). Effects of Budgetary Goal Characteristics on Managerial Attitudes and Performance. The Accounting Review, Vol 54, No.4, pp. 707-721.

LAN BPKP - Lembaga Administrasi Negara dan Badan Pengawas Keuangan dan Pembangunan RI. (2004). Akuntabilitas dan Good Governance, Modul 1, Modul Sosialisasi Sistem Akuntabilitas Kinerja Instansi Pemerintah, Jakarta

March, J. G., Olsen, J. P.. \& Christensen, S. (1976). Ambiguity and Choice in Organizations. Universitetsforlaget.

Mulyadi A.R,S., \& Efendy, D. (2018). Pengaruh Sistem Pelaporan dan Kejelasan Sasaran Anggaran Terhadap Akuntanbilitas Kinerja Instansi Pemerintah (Studi Pada Satuan Kerja Pemerintah Aceh). Jurnal Riset Inspirasi Manajemen Dan Kewirausahaan, 2(2), 95-101. https://doi.org/10.35130/jrimk.v2i2.21

Primarisanti, H., \& Akbar, R. (2015). Factors Influencing the Success of Performance Measurement: Evidence From Local Government. Journal of Indonesian
Economy and Business, 30(1), 56. https://doi.org/10.22146/jieb.7334

Putri, G. E., \& Kamilah, F. (2019). Pengaruh Faktor - Faktor Teknis dan Organisasional Terhadap Pengembangan Sistem Pengukuran Kinerja. Jurnal Ilmiah Ekonomi dan Bisnis, 16(1), 10-18.

Rangkuti, M. H. B. (2018). Akuntabilitas Kinerja Di Instansi Pemerintah (Studi Empiris pada Pemerintah Kabupaten Deli Serdang. Jurnal Akuntansi Bisnis dan Publik, 8(2), 1-14.

Sihaloho, F. L. dan Halim, A. (2005). Pengaruh Faktor-Faktor Rasional, Politik, dan Kultur Organisasi terhadap Pemanfaatan Informasi Kinerja Instansi Pemerintah Daerah. In Simposium Nasional Akuntansi VIII.

Sofyani, H., \& Akbar, R. (2013). Hubungan Faktor Internal Institusi Dan Implementasi Sistem Akuntabilitas Kinerja Instansi Pemerintah (Sakip) Di Pemerintah Daerah. Jurnal Akuntansi Dan Keuangan Indonesia, $\quad 10(2), \quad$ 184-205. https://doi.org/10.21002/jaki.2013.10

Tribunnew.(2019).https://pekanbaru.tribunnew s.com/2019/02/04/wako-kesal-nilai-sakipkota-pekanbaru-hanya-naik-118-persen, yang di akses pada tanggal 24 Desember 2019

Wijaya, A. H. C., \& Akbar, R. (2013). The influence of information, organizational objectives and targets, and external pressure towards the adoption of performance measurement system in public sector. Journal of Indonesian Economy and Business, 28 (1), 62-83.

Zulfiandri, A. (2017). Faktor-Faktor Yang Mempengaruhi Akuntabilitas Kinerja Instansi Pemerintah. Jurnal Riset Akuntansi Tirtayasa, 7(1), 45-56. 